\title{
Self-access Language Learning for Malaysian University Students
}

\author{
Andrew Yau Hau Tse ${ }^{1}$ \\ ${ }^{1}$ Centre of Modern Languages and Human Sciences, Universiti Malaysia Pahang, Malaysia \\ Correspondence: Andrew Yau Hau Tse, Centre of Modern Languages and Human Sciences, Universiti Malaysia \\ Pahang, Gambang, Kuantan, Malaysia. Tel: 6-09-549-3067. E-mail: ayhtse@ump.edu.my
}

Received: October 27, 2012 Accepted: November 9, 2012 Online Published: November 14, 2012

doi:10.5539/elt.v5n12p163 URL: http://dx.doi.org/10.5539/elt.v5n12p163

\begin{abstract}
Just a few Malaysian universities offer self-access language learning activities to students. The objective of this study is to investigate if self-access learning can promote self-directed or autonomous learning in a public Malaysian technical university. Data collection is by means of interviewing the Director, lecturers, and students in a self-access language learning centre (SALLEC). The findings revealed students find it helpful and useful to exploit the self-learning materials in the centre. Lecturers strongly agree that the centre can promote autonomous learning. To conclude, self-learning should be promoted in Malaysia to enhance language learning and acquisition.
\end{abstract}

Keywords: self-access learning, language learning

\section{Introduction}

\subsection{Background of Study}

In Malaysia, English is taught as a second language. Students lack motivation and they do not know how and where to advance their English skills except by waiting for their teachers to feed them an explicit instruction in the classroom. Many English teachers still base their teaching on grammar rules, rote learning, and textbook-bound lectures. Many English textbooks are dry, with a lot of grammar exercises and reading passages which do not relate to the learners' lives and interests. Consequently, learners find English classrooms highly impractical and boring. Yet they like watching movies, singing English songs, and using the Internet to surf information. However, these learning activities are always overlooked and received little support among teachers and parents.

\subsection{Problem Statement}

University students rely heavily on the lecturers and lecture notes for learning. This will hinder their critical, analytical, and creative thinking. Teacher-centred, rather than student-centred, activities are conducted in the classroom.

\subsection{Objectives of Study}

The objectives are threefold:

a) To design a language learning model for Universiti Malaysia Pahang (UMP) students via self-access language learning experience;

b) To develop English learning activities and apply them to UMP students;

c) To test the validity and effectiveness of this learning model.

\subsection{Research Questions and Hypotheses}

RQ1: Will university students accept the notion of self-access learning?

H1: Since students rely too much on the lecturers for their study, they may not accept this notion.

RQ2: Is it difficult to promote self-access learning in Malaysian universities?

H2: Since self-access learning mode is uncommon in Malaysia, it may take some time to promote this kind of learning to students. 


\subsection{Significance of Study}

The result of the present study will benefit students, lecturers, educators, government officials, and researchers since self-access learning is something new in Malaysia.

\subsection{Scope of Study}

This study will involve all UMP students in Gambang, especially first year students. Online language learning websites will be provided in, for instance, listening, speaking, reading, and writing. These sites will be uploaded on the Centre of Modern Languages and Human Sciences (CMLHS) portal for one semester (3.5 months). Language teachers and lecturers are also involved in this research.

\section{Literature Review}

Nowadays students engage themselves in out-of-class (OOC) activities to learn English. OOC means any non-assignment activities that learners do in English language either academic or non-academic related when they are outside of formal classroom setting with or without intention to learn or practise English. In other words, students can learn English unconsciously in the OOC setting.

Benson (2001:62) defines OOC as any type of learning that occurs outside the classroom which includes 'self-instruction, naturalistic learning or self-directed naturalistic learning'. Researchers started to pay attention to language learning in OOC context only thirty-four years ago when the first major study concerned with OOC and language proficiency was conducted by Seliger (1977).

Seliger (1977) identified two types of learners: a) high-input generators (=learners who were active in classroom interaction as well as consciously work on their English outside the classroom) and b) low-input generators (=learners who are passive in their English learning both in and out of the classroom. The present study has a focus on the second type of learners.

Nunan (1989) started his research by studying forty-four successful EFL (=English as a Foreign Language) learners in Southeast Asian countries to explore the common efficient patters in their learning. The learners provided a list of OOC activities and variety of sources outside the classroom. Further, he surveyed advanced students to rank factors that help enhancing their EFL competency (Nunan, 1991). The top three answers were: a) conversation with English speakers or in groups; b) finding opportunities to practise English outside the classroom; and c) accessing media such as radio, TV, and newspapers. Clearly, Nunan's studies revealed that, outside the classroom, successful learners activating language via utilizing supply of resources. In addition, "the determination to apply their developing language skills outside the classroom" (Nunan, 1991:175) is pivotal for learners' L2 (=second language) development.

Freed (1990) explored the OOC French use of a group of thirty-eight learners in a study abroad programme in France. Her findings depicted that different learners benefited from different activities. Low competency learners tended to benefit from interacting with people more than higher level students did while high competency learners profited from interacted with materials such as newspapers, book, and TV. She noted that low competence learners who were more involved in interactive context tended to show distinct improvement in English learning.

Self-access language learning centres (SALLECs) can help students acquire English and assist formal classroom teaching. "...self-access centres encourage attendees to be extremely competent and resourceful language, cultural, and social learners" (Nathan, 2011:19). Hence SALLEC is chosen to be the source of data for analysis.

\section{Methodology}

Qualitative research method is employed in this study. Data collection is by means of interviewing the Director, lecturers, and students in one Self-access Language Learning Centre in Malaysia, that is, Nottingham University in Kuala Lumpur, to examine the current self-learning activities. It is noted that just a few universities in Malaysia offer self-access language learning support to undergraduate and postgraduate students. Data collected from the centre were analysed leading to the creation of a learning model. In order to check the effectiveness of this centre, a virtual self-access centre (VSAC)(see Appendix A) is uploaded on the CMLHS portal for one semester (3.5 months) for student use. The frequency of using this virtual centre is recorded.

\section{Results and Discussion}

\subsection{Result}

The SALLEC is established by the Centre for English Language Education (CELE) in 1992 to help international students improve their English for academic study at the University of Nottingham in Malaysia. CELE has built 
up a reputation as a student-centred organization committed to empowering its students to succeed in their chosen academic and professional fields. Online tutors (members of staff at CELE) stand by for individual online consultations. The objective of SALLEC is to improve specific language skills such as listening, speaking, reading, writing, vocabulary, and study skills. With the presence of the discussion board, students can share ideas, information, and comments with other international students. Students find it useful and helpful in learning English and tutors find it practical to help students learn English.

On the usage of the VSAC, table 1 (Appendix B) shows the majority of students (181 hits) made use of the listening websites to improve their listening comprehension skills. The lowest usage is vocabulary (6 hits), perhaps they think that this is unimportant. Overal, the usage is very low which indicates that students are not aware of self-learning and their attitude towards autonomous learning is very weak.

To answer the research questions, based on the above table, university students do not accept the notion of self -access language learning and it may take a long time to promote this kind of learning to students. Actually self-access learning has been developed in advanced countries two decades ago since educators believe that this can help students learn English.

\subsection{Discussion}

In UMP scenario, CMLHS offers university core subjects and training courses such as the IELTS for academic staff. These courses aim at enhancing language, communication, and human development skills for students as well as for external clients. Teaching in the classroom is mostly teacher-centred, with less student-centred activities. Regarding these pedagogic activities, a different approach is indispensable to improve its efficacy. Further steps should be taken to foster self-directed, autonomous learning in the students, which is a component in the generic skills identified by UMP and an ability that would prove to be pivotal to the students in the future. For the sake of students, a Self-access Centre should be esstablished to help our students to widen their perspecives in learning and to train their analytical, creative, and critical thinking via self-learning.

The notion of SALLEC can be borrowed by CMLHS to promote self-learning, which is different from formal classroom learning. A language learning model is, therefore, created for UMP students, as shown in figure 1 (Appendix C).

Holec (1981) states that "autonomous learning requires the skill of taking responsibility and control of the learning process. Responsible learners "accept the idea that their own efforts are crucial to progress in learning, and behave accordingly" (Scharle \& Szabó, 2000, p. 3). Actually, autonomy constitutes the core of learning. Longworth (2003) believes ownership of learning belongs to the learner, not the teacher, "a 180-degree shift of emphasis and power from provider to receiver". Autonomy makes students to be more sophisticated and equipped as learners, therefore, "teachers who want to empower students to make decisions and resolve their own problems will give students opportunities to think, act, and take responsibility" (Charles, 1999, p. 221).

As we know, learning is closely associated with autonomy. Little (2007) argues that "the development of learner autonomy and the growth of target language proficiency are mutually supporting and fully integrated with each other". According to Scharle \& Szabó (2000), there are three stages in the development of autonomy, namely i) Raising awareness, ii) Changing attitudes; and iii) Transferring roles.

It is apparent that autonomous learning demands a role change of both teachers and students in any stage. In the autonomous learning context, teachers start to share the responsibility for learning with students. Santrock (2006) states that "teachers serve as facilitators and guides rather than directors and moulders of [...] learning". Slavin (1997) further argues that in the student-centred classrooms, teachers become " "the guide on the side' instead of 'the sage on the stage' helping students to explore their own meaning instead of lecturing and controlling all classroom activities". Nakamura (2000) suggests that teachers should be open to constructing a good relationship with students. Thus, the attitude regarding teacher-role is changing too.

Based on the above suggestions, in order to effectively learn the English language, university students i) should be conscious of the importance of self-learning; ii) have to change their attitude of learning, that is , from teacher-centred to self-centred; and iii) change their role from passive to active self-directed learners.

\section{Conclusion and Recommendations}

\subsection{Conclusion}

SALLEC is widely used and accepted in universities all over the world but this is uncommon in Malaysia context. University administrators and academics do not see its benefits and impacts on student learning. They still rely on formal traditional classroom teaching. This mind-set should be changed from teacher-centred to 
student-centred learning, which is more effective.

As mentioned above, educators and academics in Malaysia are not aware of the importance of autonomous learning and therefore do not promote self-access learning. In fact, this has been promoted in Europe, the USA, Canada, and Australia for many years. The Malaysian government should follow suit, set up a SALLEC in each university and help the learners learn English by using the facilities in the centre since it benefits them profoundly.

\subsection{Recommendations}

There are a couple of limitations in this study. First of all, the data collected came from one SALLEC only. More SALLECs, from local or overseas, should be included so that comparison can be made within these centres. Second, this is a mini scale research. More research are needed to explore the feasibility and applicability of establishing SALLECs in Malaysia. It is hoped that this paper can enlighten the Malaysia Ministry of Education in self-access language learning in tertiary institutes.

\section{References}

Benson, P. (2001). Teaching and researching autonomy in language learning. Harlow: Pearson Ed.

Charles, C. M. (1999). Building classroom discipline. USA: Addison Wesley, Longman.

Freed, B. F. (1990). Language learning in a study abroad context: The effects of interaction and non-interactive out-of-class contact on grammatical achievement and oral proficiency. In J. E. Alatis (Ed.), Linguistics, language teaching, and language acquisition: The interdependence of theory, practice, and research (pp. 459-477). Washington, DC: Georgetown University Press.

Holec, H. (1981). Autonomy and foreign language learning. Oxford: Pergamon Press Pergamon. (First published 1979, Strasbourg: Council of Europe).

Little, D. (2007). Language learner autonomy: Some fundamental considerations revisited. Innovation in Language Learning and Teaching, 1(1), 14-29. http://dx.doi.org/10.2167/illt040.0

Longworth, N. (2003). Lifelong learning in action: Transforming education in the $21^{\text {st }}$ century. Great Britain: Kogan Page.

Nakamura, R. M. (2000). Healthy classroom management. USA: Wadsworth.

Nathan, P. K. et al. (2011). Language Learning Through Socialization: Diversified Use of a Self-Access Center. International Journal of Social Science and Humanity, 1(1), 19-25.

Nunan, D. (1989). Designing Tasks for the Communicative Classroom. New York: Cambridge University Press.

Santrock, J. W. (2006). Educational psychology. Boston: McGraw-Hill Higher Education.

Scharle, Á., \& Szabó, A. (2000). Learner autonomy: A guide to developing learner responsibility. Cambridge: Cambridge University Press.

Seliger, H. (1977). Does practice make perfect? A study of interaction patterns and L2 competence. Language Learning, 27, 264-278. http://dx.doi.org/10.1111/j.1467-1770.1977.tb00122.x

Slavin, R. E. (1997). Educational psychology and smart schools. Boston: Prentice Hall.

\section{Appendix A}

An example of self-learning websites in the Virtual Self-access Centre (VSAC)

※ Listening Materials $*$

\section{a) Randall's ESL Cyber Listening Lab}

This site contains listening quizzes for academic purpose at various levels of difficulty and for TOEFL preparation.

\section{b) Links - Sounds of English}

This site contains general ESL listening activities, for instance, BBC World Service, English learning lounge, speeches, songs, poetry, and many more.

\section{c) http://www.learnenglishfeelgood.com/eslvideo/}

Learning through media (movies, music etc.) is one of the best ways to learn a new language. The video clips in this site will improve your listening comprehension skills, helping you to learn and practice English as spoken by normal people every day! These particular clips are from recent movies. 


\section{d) http://esl-bits.net/}

This is a site on ESL intermediate and advanced listening. It contains American oriented songs, radio dramas, and audio-books.

\section{Appendix B}

Table 1.

\begin{tabular}{ll}
\hline Language skills & No. of hits for 3.5 months \\
\hline Listening & 181 \\
\hline Speaking & 22 \\
\hline Reading & 16 \\
\hline Writing & 34 \\
\hline Grammar & 21 \\
\hline Pronunciation & 20 \\
\hline Vocabulary & 6 \\
\hline IELTS & 12 \\
\hline Study skills & 8 \\
\hline Reference skills & 7 \\
\hline
\end{tabular}

Appendix C

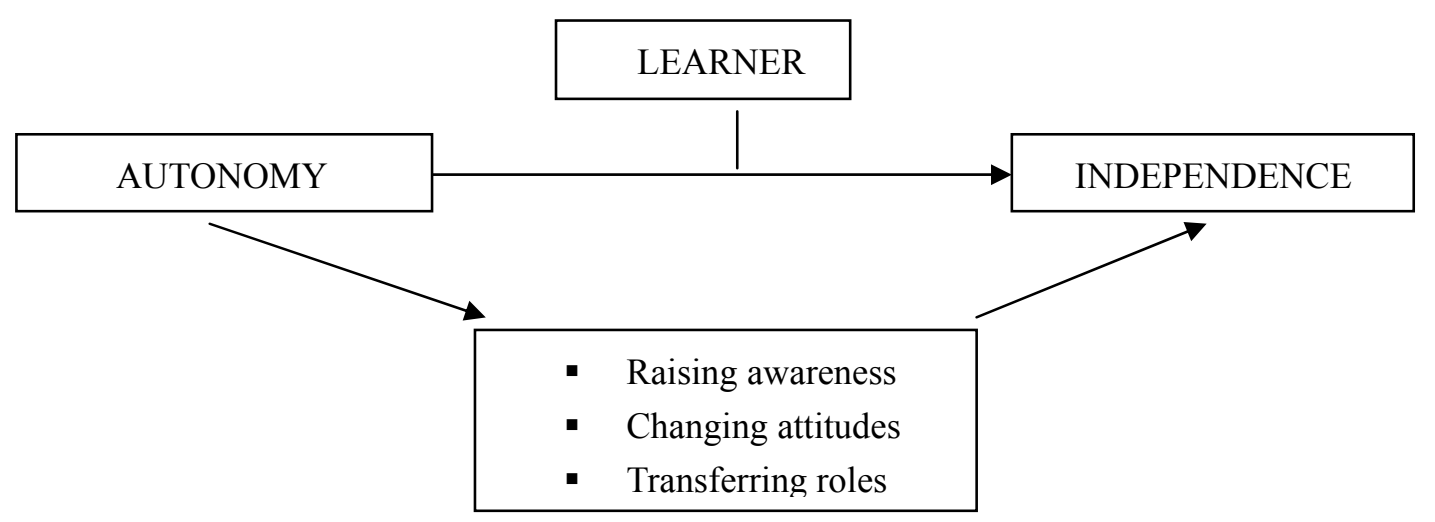

Figure 1. Language Learning Model 